\title{
A New Species of Agrostis (Poaceae, Pooideae, Poeae, Agrostidinae) from the Andean Páramos of Colombia and Ecuador
}

\author{
Patricia Candela Palacio, ${ }^{1 *}$ Ana María Molina, ${ }^{2}$ Zulma Esther Rúgolo de Agrasar, ${ }^{3,4}$ and \\ Andrea Susana Vega $a^{1,4}$ \\ ${ }^{1}$ Universidad de Buenos Aires, Facultad de Agronomía, Departamento de Recursos Naturales y \\ Ambiente, Cátedra de Botánica General, Av. San Martín 4453, C1417DSE, Buenos Aires, Argentina. \\ ${ }^{2}$ Jardín Botánico Arturo E. Ragonese (JBAER), Instituto Nacional de Tecnología Agropecuaria, De Los \\ Reseros y Nicolás Repetto s. n., 1806, Hurlingham, Buenos Aires, Argentina. \\ ${ }^{3}$ Instituto de Botánica Darwinion, Labardén 200, Casilla de correo 22, B1642HYD, Buenos \\ Aires, Argentina. \\ ${ }^{4}$ Carrera del Investigador Científico, Consejo Nacional de Investigaciones Científicas y Técnicas \\ (CONICET), Argentina. \\ *Author for correspondence: ppalacio@agro.uba.ar
}

Abstract. Agrostis laegaardii A. M. Molina \& Rúgolo (Poaceae), a new species restricted to the high páramos from Colombia and Ecuador, is described and illustrated. It is morphologically most similar to A. breviculmis Hitchc. but differs in spikelet length, pedicel apex, glume texture, relative distance between upper glume and floret, lemma and palea length, and the presence of an awn on the lemma. Micromorphology of the spikelet is discussed, and a Trichodium net is reported on the epidermis of the lemma. A distribution map and a key to the Colombian and Ecuadorean species of Agrostis L. with contracted inflorescences are provided.

Key words: Agrostidinae, Agrostis, high páramos, Trichodium net.

The grass subtribe Agrostidinae Fr. (Poaceae, Poeae) is composed of 409 species distributed in 11 genera (Soreng et al., 2017). One of these genera is Agrostis L., which comprises about 224 species (Soreng et al., 2017) and has a wide geographical distribution in temperate and cold regions of both hemispheres and in mountains of tropical and subtropical regions. In America, two important centers of species diversification are present, one in the Andean Patagonian region of Argentina and Chile, where many native species occur, some of them endemic (Rúgolo de Agrasar \& De Paula, 1978; Nicora \& Rúgolo de Agrasar, 1987; Rúgolo de Agrasar \& Molina, 1990, 1992, 1993, 1998), and the other in the southwestern United States and Mexico (Molina \& Rúgolo de Agrasar, unpubl. data). In Ecuador, there are several contributions on Agrostis (Sodiro, 1889, 1930; Hitchcock, 1927; Espinosa, 1949; Acosta Solís,
1969; Jørgensen \& Ulloa Ulloa, 1994), and 11 species have been cataloged in Jørgensen and León-Yánez (1999). Recent studies of Colombian grasses (GarcíaUlloa et al., 2005) included four new records in Agrostis. Later, Giraldo-Cañas (2011) prepared an inventory of the Colombian species of Poaceae and reported 14 species of Agrostis.

The present work is part of a taxonomic revision of Agrostis for the Neotropical regions of America (Molina \& Rúgolo de Agrasar, unpubl. data). Agrostis laegaardii A. M. Molina \& Rúgolo, a new species from the páramos of Colombia and Ecuador, is here described and illustrated and its known geographic distribution is provided. Details of the spikelet, as well as the epidermis of the lemma, are analyzed and SEM photomicrographs are included. A key to differentiate A. laegaardii from morphologically similar taxa in this region is provided.

In Agrostis, the morphology of the inflorescence is useful for the identification of species (Rúgolo de Agrasar \& Molina, 1992, 1998). Two different types of inflorescences are recognized: contracted inflorescences with more or less appressed branches and lax inflorescences with divergent branches at maturity that do not exceed the total length of the inflorescence. The inflorescences of $A$. laegaardii belong to the first type, as do those of several other taxa of Agrostis in Ecuador (i.e., A. boyacensis Swallen \& García-Barr., A. breviculmis Hitchc., A. foliata Hook. f., A. meyenii Trin., A. tolucenis Kunth var. tolucensis, and A. tolucensis var. andicola (Pilg.) Rúgolo \& A. M. Molina) and Colombia (A. stolonifera L. var. palustris (Huds.) Farw.). The morphologically most similar species to $A$. laegaardii is A. breviculmis, which is widely distributed in South 
America, where it occurs in high mountains from Colombia to Chile and Argentina (Rúgolo de Agrasar \& Molina, 1992, 1993, 1998). These two species differ from the others in Colombia and Ecuador in being caespitose plants with short rhizomes, forming basal cushions, and having convolute, chartaceous leaf blades with navicular apices and glumes with shiny prickle hairs along the keel.

\section{Materials and Methods}

Macromorphological, micromorphological, and anatomical studies were carried out using specimens from AAU, BAB, QCA, QCNE, SI, and US (Thiers, 2019), according to traditional taxonomic methods. A list of selected material examined is presented (Appendix 1).

For micromorphological studies the spikelets were selected from herbarium specimens, cleaned with xylene, and coated with a gold-palladium (40\%/60\%) alloy using a sputter coater (Thermo Fisher Scientific, West Sussex, U.K.). The micromorphology of the spikelets was analyzed with a Phillips XL 30 (Phillips, Einhoven, the Netherlands) Scanning Electron Microscope (SEM) at the Museo Bernardino Rivadavia (Buenos Aires, Argentina). Observations were made of the abaxial epidermis of the lemmas (middle zone) of spikelets attached in the middle zone of the inflorescence branches.

The texture of the glumes was compared with their anatomy at the middle zone in transverse section, according to traditional techniques (D'Ambrogio de Argüeso, 1986). The anatomical description of the glumes in cross section follows the terminology proposed by Ellis (1976).

\section{Taxonomic Treatment}

Agrostis laegaardii A. M. Molina \& Rúgolo, sp. nov. TYPE: Ecuador. Pichincha-Napo: on N-side of Volcán Antisana app. $12 \mathrm{~km}$ along dirt rd. from Hacienda Antisana, $78^{\circ} 10^{\prime} \mathrm{W} 00^{\circ} 27^{\prime} \mathrm{S}, 4600-4650 \mathrm{~m}$, in old moraines, soil partly unconsolidated due to solifluction, 15 May 1992, S. Laegaard 102881 (holotype, AAU!; isotypes, BAB!, QCA!, QCNE!). Figure 1.

Diagnosis. Agrostis laegaardii A. M. Molina \& Rúgolo is distinguished from A. breviculmis Hitchc. by having spikelets (1.7-)2-3.3 mm long (vs. 1.6-2[-2.5] mm long), pedicels slightly dilated toward the apex, cupuliform (vs. apex not dilated, truncate); glumes membranous (vs. chartaceous), lower glume narrowly ellipsoid (vs. navicular); distance between upper glume and floret (0.5-)0.7-1 mm (vs. 0.3-0.5 mm); lemma (1.4-)1.7-2 mm long, awned, dorsal awn (1.6-)2.3-3 mm long, apex shortly 4-awned, $0.5-0.6 \mathrm{~mm}$ long (vs. lemma 1.2-1.4 mm long, awnless or mucronulate, apex 4-mucronate), and palea $0.4-0.5 \mathrm{~mm}$ long (vs. $0.2-0.3 \mathrm{~mm}$ long).
Perennial herbs 6-18 cm tall, caespitose, forming hemispherical cushions; rhizomes 0.5-1 mm diam., internodes ca. $5 \mathrm{~mm}$. Innovations intravaginal and extravaginal. Culms erect, simple, shining, smooth. Leaves up to half as long as culms; sheath smooth, papyraceous, striate, longer than internodes, those of flowering shoots broader than their leaf blades, glabrous; ligule 1-2 mm, membranous, truncate, decurrent with sheath, apex obtuse, abaxially glabrous or minutely scabrous; blade 1.5-5 cm $\times 1-2 \mathrm{~mm}$, convolute, rigid, straight or recurved, abaxially shining, glabrous; adaxial surface and margins scabrous; apex obtusely navicular. Inflorescence 2-5 cm $\times 3-6 \mathrm{~mm}$, exserted at maturity; lateral branches alternate, appressed, minutely scabrous or glabrous; pedicels of spikelets $1.5-4 \mathrm{~mm}$, slightly dilated toward apex, cupuliform, glabrous or minutely scabrous. Spikelets (1.7-)2-3.3 mm, yellowish with purple tint. Glumes persistent on inflorescence, membranous, narrowly ellipsoid, subequal, 1-nerved, keeled (V-shaped in cross-section), apex acute, adaxial surface minutely scabrous on the upper half; lower glume with abundant shiny prickle hairs along keel; upper glume with abundant shiny prickle hairs along upper $2 / 3-3 / 4$ of keel. Stipe between upper glume and floret-callus (0.5-)0.7-1 mm, rachilla extension above floret absent. Callus rounded, with 2 lateral tufts of short hairs 0.1-0.2 mm. Lemma (1.4-)1.7-2 mm, 5-nerved, membranous, scabrous, apex with 4 minute awns, middle nerve prolonged in a dorsal awn (1.6-)2.3-3 mm, straight or flexuous, minutely scabrous, inserted in middle to upper third of lemma, exserted from glumes; abaxial epidermis with Trichodium net. Palea $0.4-0.5 \mathrm{~mm}$, hyaline, nerves not evident. Lodicules 2, 0.3-0.6 mm, lanceolate, unlobed, hyaline. Stamens 3 ; anthers 0.7-1 mm, purple at maturity. Ovary glabrous. Immature caryopsis brownish, longitudinally grooved; hilum punctiform; endosperm dry.

Phenology. Flowering occurs from February to May.

Etymology. Agrostis laegaardii is dedicated to Simon Laegaard, botanist and specialist in Poaceae and native flora of Ecuador, who collected the type and much of the known material.

Geographic distribution and habitat. Agrostis laegaardii is found in the high páramos of Colombia and Ecuador, forming dense tufts. In Ecuador the species was collected in the provinces of Pichincha, Napo, Pastaza, Cotopaxi, Tungurahua, and Chimborazo (Fig. 2), inhabiting a pajonal moorland according to the classification of moors proposed by Hofstede et al. (2002). In Colombia, A. laegaardii was collected near the Nevado del Ruiz, an active stratovolcano (Mejía et al., 2012). All these collections belong to the Andean 


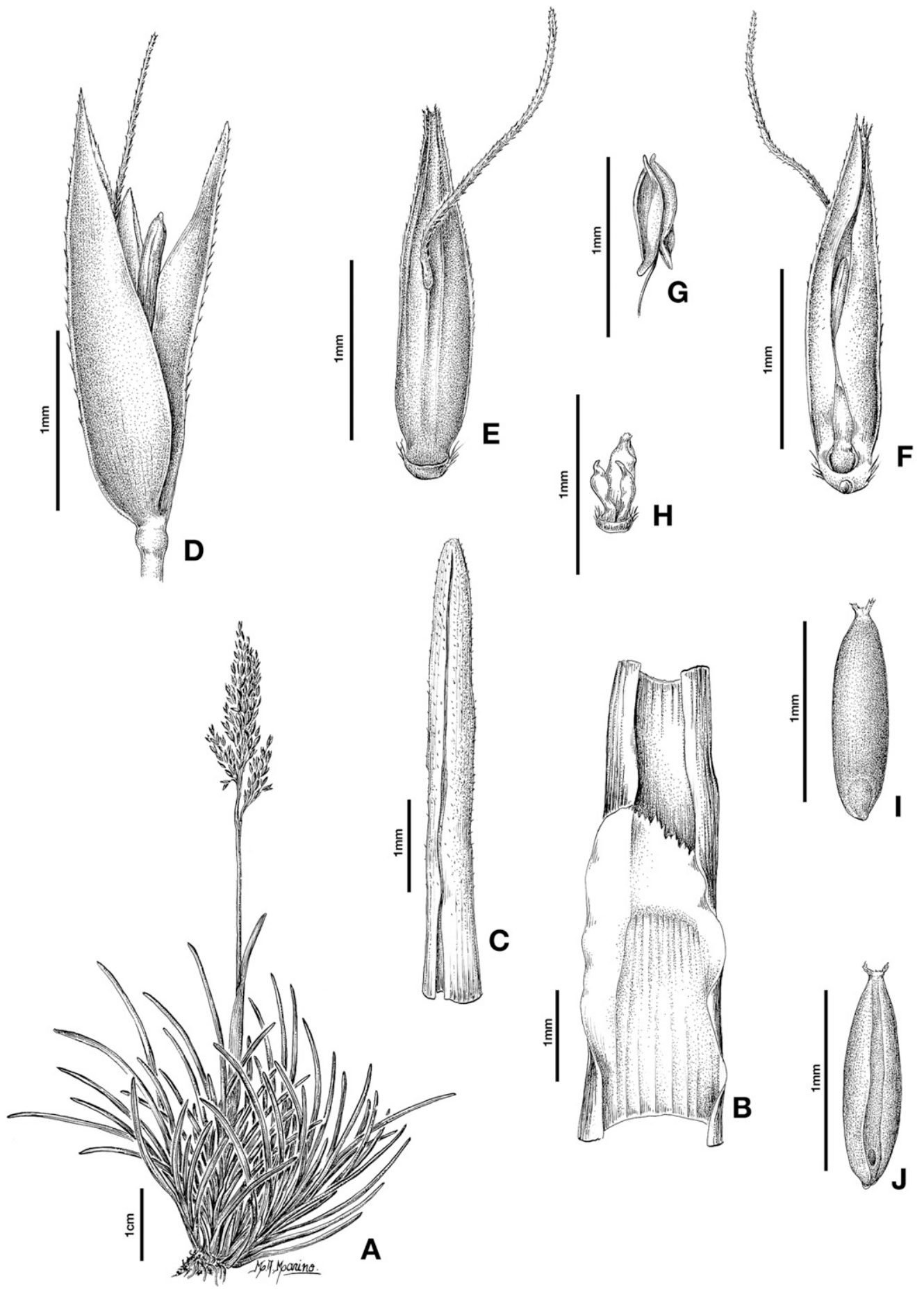

Figure 1. Agrostis laegaardii A. M. Molina \& Rúgolo. - A. Habit. -B. Ligule, ventral view. -C. Apex of the leaf. - D. Lateral view of spikelet. —E. Floret, dorsal view. — F. Floret, ventral view. - G. Stamen. —H. Callus, lodicules, and palea in ventral view. - I. Caryopsis, dorsal view. - J. Caryopsis, ventral view. All based on Laegaard 102881 (QCNE). 


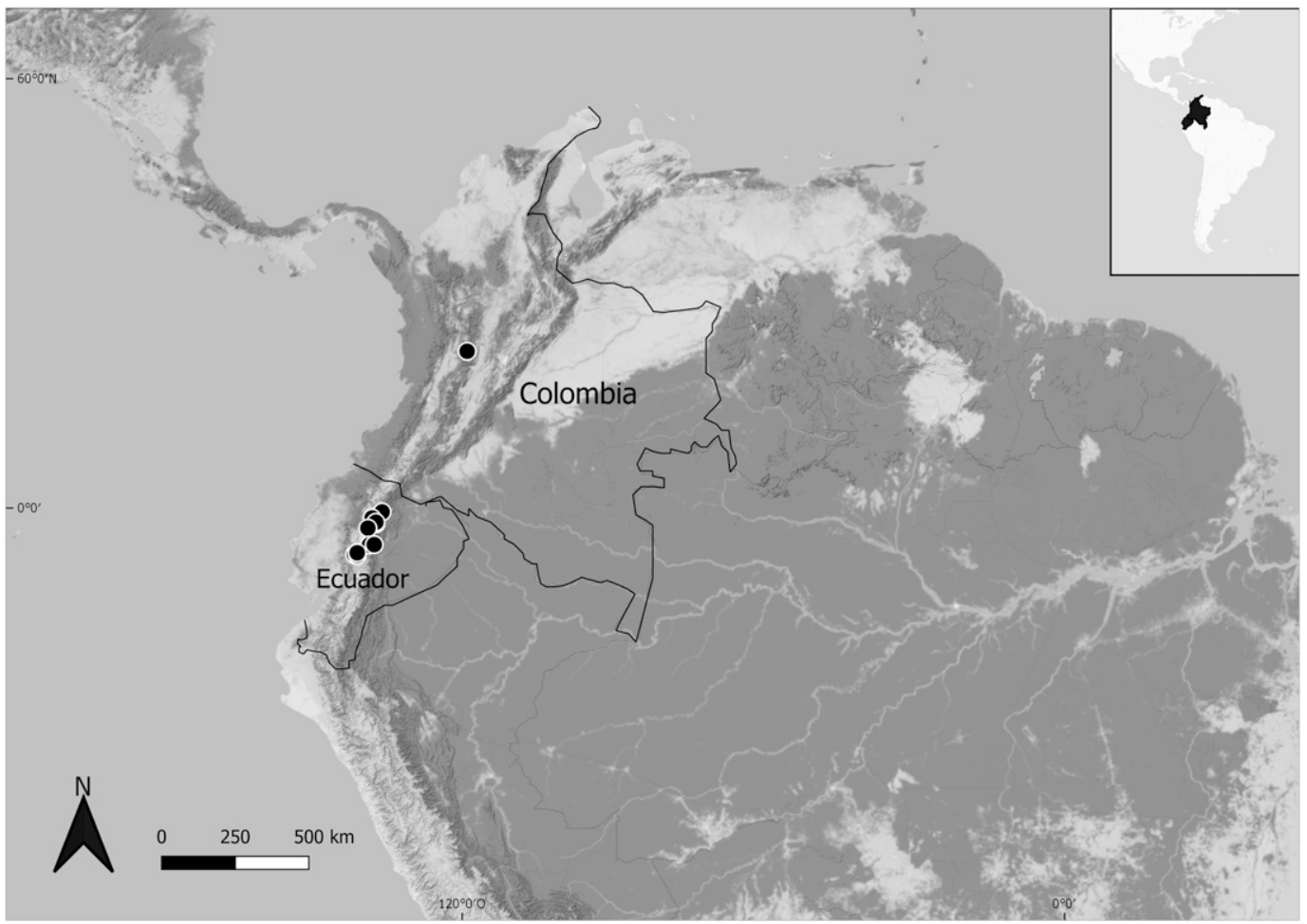

Figure 2. Geographic distribution of Agrostis laegaardii A. M. Molina \& Rúgolo.

páramos, which represent a biogeographical region of great biological diversity (Llambí \& Cuesta, 2014). These ecosystems have endemic species, provide fundamental environmental services, and are spaces of cultural importance for various traditional and local populations (Llambí \& Cuesta, 2014). Human activities (raising livestock and crops) have transformed the páramos and caused impacts on the environment (Llambí \& Cuesta, 2014). According to our records, more than 20 years have elapsed since the last collection of A. laegaardii. Therefore, field trips are necessary to target areas for conservation and sustainable management.

Notes. In addition to the characters mentioned above, Agrostis laegaardii and A. breviculmis also differ in the anatomy of the glumes in cross section. In A. laegaardii, the glumes have a standard V shape (i.e., between $45^{\circ}$ and $90^{\circ}$ to each other; Ellis, 1976) and at the margins they have only one cell layer of thickness (abaxial epidermis), whereas in A. breviculmis the glumes have a narrow $\mathrm{V}$ shape (that is, less than $45^{\circ}$ between them; Ellis, 1976) and at the margins they are two cell layers thick (adaxial and abaxial epidermis).

The structure of the lemma epidermis in Agrostis has been studied by Björkman (1960), Rajbhandari (1985), Romero García et al. (1988), and Rúgolo de Agrasar and
Molina (1992, 1998). Björkman (1960) analyzed and described transverse thickening bars on the outer tangential cell walls of the abaxial lemma epidermis and called them "Trichodium net." The presence of Trichodium net may be related to the palea development and texture. In Agrostis, species with a reduced palea exhibit Trichodium net, while it is absent in those species in which the palea reaches half the length of the floret (Björkman, 1960; Rajbhandari, 1985; Romero García et al., 1988; Rúgolo de Agrasar \& Molina, 1992, 1998). For this reason, Björkman (1960) considered that the occurrence or absence of a Trichodium net was the most useful character in the subgeneric classification of Agrostis. Agrostis laegaardii exhibits a reduced palea and its lemma epidermis has a well-developed Trichodium net (Fig. 3). According to the classification proposed by Widén (1971), A. laegaardii exhibits a Trichodium net type I. This network is fully developed with thickened transverse ribbons almost as wide as, or wider than, the non-thickened parts of the outer epidermis cell wall.

Paratypes. COLOMBIA. Caldas-Tolima: Páramo del Ruiz, 3700-4200 m, 26 Dec. 1936, Chardon 5021 (US). ECUADOR. Chimborazo: upper WSW slopes of Volcán Chimborazo, $500 \mathrm{~m} \mathrm{~S}$ of (below) the Whymper refuge, $4750 \mathrm{~m}, 78^{\circ} 50^{\prime} \mathrm{W}, 01^{\circ} 28^{\prime} \mathrm{S}, 7$ Feb. 1988, Molau \& Eriksen 2985 (AAU, QCNE); Volcán Chimborazo, above the lower 

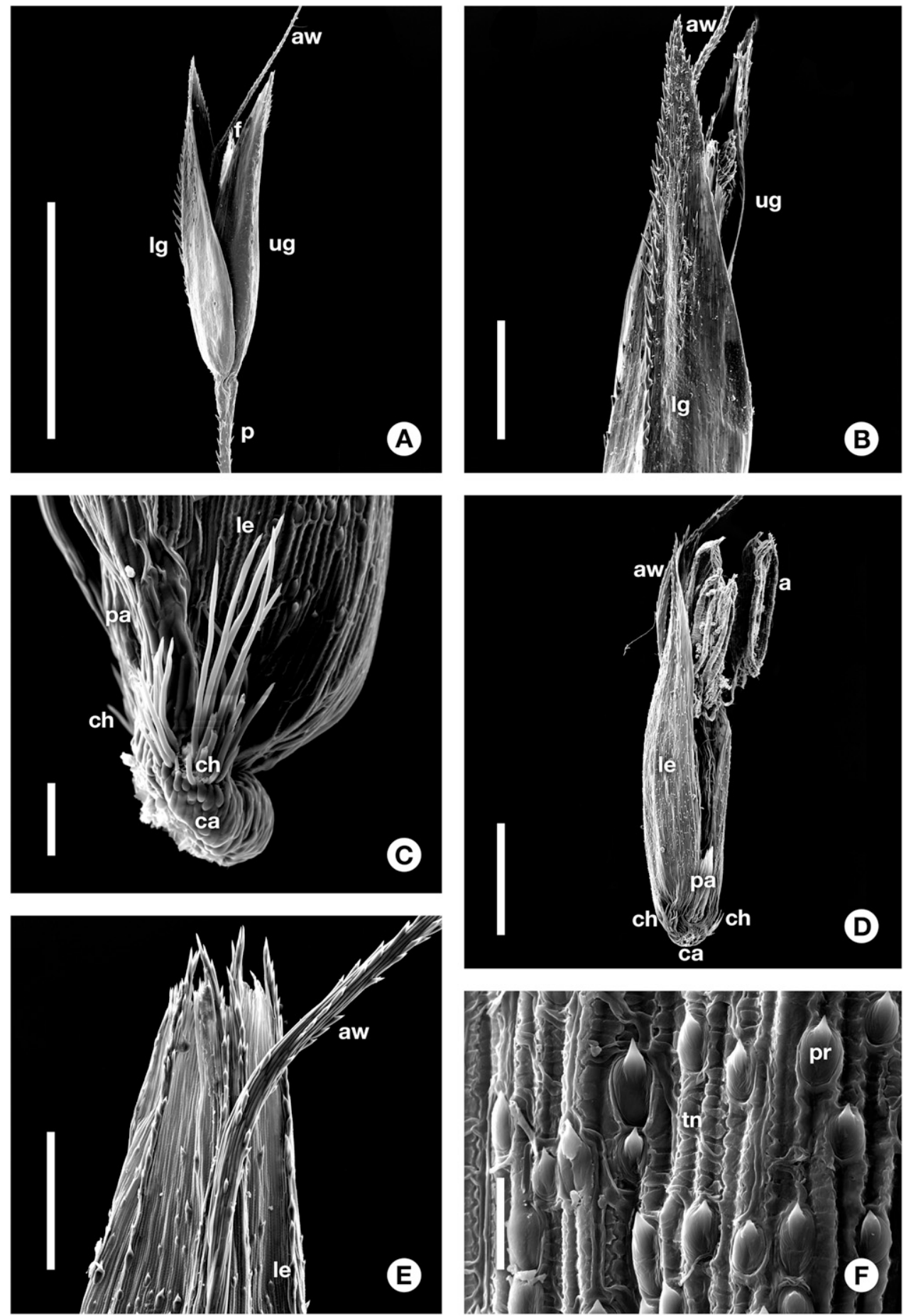

Figure 3. Agrostis laegaardii A. M. Molina \& Rúgolo. SEM microphotographs. —A. Lateral view of spikelet. -B. Upper part of the spikelet, dorsal view of the lower glume. - C. Base of the floret, callus, and callus hairs. -D. Lateral view of the palea. - E. Dorsal view of lemma apex, in the foreground part of the dorsal lemma awn. - F. Lemma epidermis. Bars: $\mathrm{A}=2 \mathrm{~mm} ; \mathrm{B}, \mathrm{D}=$ $500 \mu \mathrm{m} ; \mathrm{C}=50 \mu \mathrm{m} ; \mathrm{E}=200 \mu \mathrm{m} ; \mathrm{F}=20 \mu \mathrm{m}$. A-D from Laegaard 102877 (QCNE); E, F from Molau \& Eriksen 2985 (QCNE). Abbreviations: a, anther; aw, awn; ca, callus; ch, callus hairs; f, floret; le, lemma; lg, lower glume; p, pedicel; pa, palea; pr, prickle; tn, Trichodium net; ug, upper glume. 
Refugio (4840 m), $5070 \mathrm{~m}, 78^{\circ} 50^{\prime} \mathrm{W}, 01^{\circ} 28^{\prime} \mathrm{S}, 11$ May 1992, Laegaard 102822 (QCNE); campsite above Río Alao, 3350-3550 m, 20 May 1990, Peterson et al. 9195 (US); betw. Urbina \& Mt. Chimborazo, 3600-4500 m, 4 Oct. 1923, Hitchcock 21982 (US). Napo: Laguna San Marcos, NE of Volcán Cayambe, extensive flat plain $\mathrm{S}$ of the lake, $3370 \mathrm{~m}, 77^{\circ} 58^{\prime} \mathrm{W}$, $00^{\circ} 07^{\prime}$ S, 8 July 1980, Laegaard 34011 (SI), Laegaard 34061 (SI); NW slope of Antisana, Lago Mauca-Machay, $4350 \mathrm{~m}$, $78^{\circ} 10^{\prime} \mathrm{W}, 00^{\circ} 27^{\prime} \mathrm{S}, 2$ Nov. 1979, Laegaard 20730 (SI); Volcán Antisana, $4600 \mathrm{~m}, 00^{\circ} 30^{\prime} \mathrm{W}, 78^{\circ} 10^{\prime} \mathrm{S}, 22$ July 1997 , Laegaard 2745 (AAU); W side of Mt. Cayambe, 4050-4350 m, 22-23 July 1943, Little \& Paredes 6881 (US). Napo-Pastaza: alrededores de Llanganates, entre Anchiliví y Río Burro Potrero, al este de Romo Páramo, 3500-3620 m, 30 Aug. 1959, Barclay
\& Juajibioy 9172 (US). Pichincha: Pifo-Pintag, in valley 2 1/2 hour horse ride above Inga Monserat, 3625-3725 m, $78^{\circ} 17^{\prime} \mathrm{W}, 00^{\circ} 19^{\prime} \mathrm{S}, 11$ Apr. 1992, Laegaard 102236 (AAU). Pichincha-Cotopaxi: Volcán Cotopaxi, NE slope at rd. to El Refugio, 4600-4800 m, 78 $25^{\prime} \mathrm{W}, 00^{\circ} 38^{\prime} \mathrm{S}, 2$ Oct. 1976 , Ollgaard \& Balslev 9977 (AAU). Pichincha-Napo: on N side of Volcán Antisana, ca. $12 \mathrm{~km}$ along dirt rd. from Hacienda Antisana, $4410-4830 \mathrm{~m}, 78^{\circ} 10^{\prime} \mathrm{W}, 00^{\circ} 27^{\prime} \mathrm{S}, 15$ May 1992, Laegaard 102877 (QCNE); same loc., on old moraine, 4700 m, 15 May 1992, Laegaard 102890 (AAU). Tungurahua: Cordillera de Llanganates, Páramo de Jaramillo, $4000-4250 \mathrm{~m}, 78^{\circ} 22^{\prime} \mathrm{W}, 01^{\circ} 10^{\prime} \mathrm{S}$, Nov. 1984, Laegaard 53315 (AAU); Mt. Carihuairazo, 4400 m, 22 Sep. 1939, Asplund 8467 (US).

Key to Agrostis Species of Colombia and Ecuador Having a Contracted Inflorescence at Maturity with More or Less Appressed BRANCHES

1. Plants stoloniferous, $30-100 \mathrm{~cm}$ high; palea $0.7-1.1 \mathrm{~mm} \ldots \ldots \ldots \ldots \ldots$. stolonifera L. var palustris (Huds.) Farw.

$1^{\prime}$. Plants rhizomatous, $3-30(-51) \mathrm{cm}$ high; palea $0.1-0.7 \mathrm{~mm}$.

2. Leaf blades convolute, rather rigid, $0.5-2 \mathrm{~mm}$ wide; plants caespitose, with thick short rhizomes, internodes 1-2 mm.

3. Spikelets (1.7-)2-3.3 mm; pedicels slightly dilated toward apex, cupuliform; glumes membranous, standard $\mathrm{V}$ shape in transverse section; lower glume narrowly ellipsoid; distance between upper glume and floret (0.5-)0.7-1 mm; lemma (1.6-)1.7-2 mm, dorsal awn (1.6-)2.3-3 mm long, apex shortly 4-awned, $0.5-0.6 \mathrm{~mm}$ long; palea $0.4-0.5 \mathrm{~mm} \ldots \ldots \ldots \ldots \ldots \ldots \ldots \ldots \ldots$. laegaardii A. M. Molina \& Rúgolo

$3^{\prime}$. Spikelets 1.6-2(-2.5) mm; pedicel not dilated at apex, truncate; glumes chartaceous, narrowly V-shaped in transverse section; lower glume navicular; distance between upper glume and floret $0.3-0.5 \mathrm{~mm}$; lemma 1.2-1.4 mm, apex 4-mucronate, awnless or mucronulate; palea $0.2-0.3 \mathrm{~mm} \ldots \ldots \ldots$. . breviculmis Hitchc.

$2^{\prime}$. Leaf blades conduplicate or flat, rather soft, 1-6 mm wide; plants with thin, well-developed rhizomes, sometimes creeping, internodes 7-9 mm.

4. Floret awnless, mucronate or rarely with a subapical short awn ca. $1.2 \mathrm{~mm}$ long; leaf blades 1.5-2 mm wide.

5. Lemma 1.7-2.6 mm; glumes subequal, both scabrous along upper third of keel; pedicels smooth,

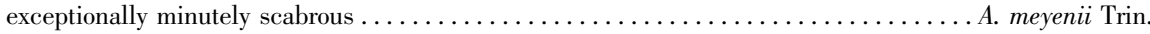

5'. Lemma 1.4-1.5 mm; glumes unequal, lower glume longer than upper one, lower glume scabrous along entire length of keel, upper glume smooth or scabrous in upper third on surface; pedicels scab-

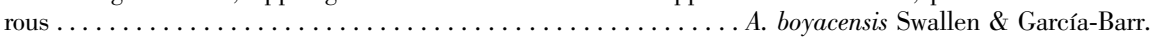

4'. Floret awned, the awn 2-6 mm, geniculate and twisted, exserted from glumes; leaf blades 1-6 mm wide.

6. Spikelets 3.5-4 mm; floret $1 / 2$ the length of the spikelet; inflorescence $1-2.5 \mathrm{~cm}$ wide, with lateral branches up to $7 \mathrm{~cm}$ long; leaf blades $2-6 \mathrm{~mm}$ wide ................. foliata Hook. $\mathrm{f}$.

6'. Spikelets (2-)2.5-3(-3.5) mm; floret ca. 2/3 the length of the spikelet; inflorescence $0.5-1.5 \mathrm{~cm}$ wide, with lateral branches $0.5-1.5 \mathrm{~cm}$ long; leaf blades $1-4(-5) \mathrm{mm}$ wide.

7. Awn inserted at the lower $1 / 3$ of the back of the lemma........ A tolucensis Kunth var. tolucensis $7^{\prime}$. Awn inserted in the upper or middle $1 / 3$ of the back of the lemma $\ldots \ldots \ldots \ldots \ldots \ldots \ldots$ $\ldots \ldots \ldots \ldots \ldots \ldots \ldots \ldots \ldots$. tolucensis var. andicola (Pilg.) Rúgolo \& A. M. Molina

Acknowledgments. We are indebted to Simon Laegaard, R. Soreng, and an anonymous reviewer for their useful suggestions to improve our manuscript. We extend gratitude to the curators of the herbaria and María A. Marino (INTA, Castelar, Argentina) for the illustration of the species.

\section{Literature Cited}

Acosta Solís, M. 1969. Glumifloras del Ecuador. Catálogo Fitogeográfico de las Gramíneas, Cyperáceas y Juncáceas. $1^{\circ}$ Contribución del Instituto Ecuatoriano de Ciencias Naturales al Programa Internacional de Biología, Quito.

Björkman, S. O. 1960. Studies in Agrostis and related genera. Symb. Bot. Upsal. 17: 1-112.

D’Ambrogio de Argüeso, A. 1986. Manual de Técnicas en Histología Vegetal. Hemisferio Sur, Buenos Aires.

Ellis, R. P. 1976. A procedure for standardizing comparative leaf anatomy in the Poaceae. I. The leaf-blade as viewed in transverse section. Bothalia 12: 65-109.
Espinosa, R. 1949. Estudios Botánicos en el Sur del Ecuador. Vol. 2. Editorial Universitaria, Loja.

García-Ulloa, J. A., C. Lastra, C. Salas \& M. Medina Merchán. 2005. Estudios en gramíneas (Poaceae) de Colombia: Veinte novedades corológicas. Caldasia 27: 131-145.

Giraldo-Cañas, D. 2011. Catálogo de la familia Poaceae en Colombia. Darwiniana 49: 139-247.

Hitchcock, A. S. 1927. The grasses of Ecuador, Peru, and Bolivia. Contr. U.S. Natl. Herb. 24: 291-556.

Hofstede, R., R. Coppus, P. Mena Vásconez, P. Segarra, J. Wolf \& J. Sevink. 2002. El estado de conservación de los páramos de pajonal en el Ecuador. Ecotropicos 15: $3-18$.

Jørgensen, P. M. \& C. Ulloa Ulloa. 1994. Seed plants of the high Andes of Ecuador - A checklist. Poaceae. AAU Rep. 34: 1-443.

Jørgensen, P. M. \& S. León-Yánez. 1999. Catalogue of the Vascular Plants of Ecuador. Monogr. Syst. Bot. Missouri Bot. Gard. 75: 1-1181.

Llambí, L. D. \& F. Cuesta. 2014. La diversidad de los páramos andinos en el espacio y en el tiempo. Pp. 7-40 in F. Cuesta, J. Sevink, L. D. Llambí, B. De Bièvre \& J. Posner (editors), 
Avances en Investigación para la Conservación en los Páramos Andinos. CONDESAN, Quito.

Mejía, E. L., F. Velandia, C. A. Zuluaga, J. A. López \& T. Cramer. 2012. Análisis estructural al noreste del volcán Nevado del Ruíz, Colombia - aporte a la exploración geotérmica. Bol. Geol. (Bucaramanga) 34: 27-41.

Nicora, E. \& Z. E. Rúgolo de Agrasar. 1987. Los Géneros de Gramíneas de América Austral. Hemisferio Sur, Buenos Aires.

Rajbhandari, K. R. 1985. The genus Agrostis in Nepal. J. Jap. Bot. 60: 65-78.

Romero García, A. T., G. B. López \& C. M. Morales Torres. 1988. Revisión del género Agrostis (Poaceae) en la Península Ibérica. Ruizia 7: 1-160.

Rúgolo de Agrasar, Z. E. \& M. E. De Paula. 1978. Agrostis. Pp. 369-394 in M. N. Correa (editor), Flora Patagónica. Colecc. Ci. Inst. Nac. Tecnol. Agropecu. 8(3).

Rúgolo de Agrasar, Z. E. \& A. M. Molina. 1990. Nota taxonómica sobre el género Agrostis (Gramineae). Gayana, Bot. 47: 3-7.

Rúgolo de Agrasar, Z. E. \& A. M. Molina. 1992. Las especies del género Agrostis (Gramineae: Agrosteae) de la Argentina. Parodiana 7: 179-255.

Rúgolo de Agrasar, Z. E. \& A. M. Molina. 1993. Sinopsis taxonómica del género Agrostis (Gramineae: Agrosteae) de Bolivia. Parodiana 8: 129-151.

Rúgolo de Agrasar, Z. E. \& A. M. Molina. 1998. Las especies del género Agrostis L. (Gramineae: Agrostideae) de Chile. Gayana, Bot. 54: 91-156.

Sodiro, P. L. 1889. Gramíneas ecuatorianas de la provincia de Quito. Anales Univ. Centr. Ecuador 3: 474-484.

Sodiro, P. L. 1930. Sertula Florae Ecuadorensis. Series $4^{\mathrm{a}}$. Gramíneas Ecuatorianas, Vol. 2. L. Mille (editor). Revista del Colegio Nac. Vicente Rocafuerte 11: 55-96.

Soreng, R. J., P. M. Peterson, K. Romaschenko, G. Davidse, J. K. Teisher, L. G. Clark, P. Barberá, et al. 2017. A worldwide phylogenetic classification of the Poaceae (Gramineae) II: An update and a comparison of two 2015 classifications. J. Syst. Evol. 55: 259-290.

Thiers, B. 2019 [continuously updated]. Index Herbariorum: A global directory of public herbaria and associated staff. New York Botanical Garden's Virtual Herbarium. http:// sweetgum.nybg.org/science/ih/.

Widén, K. G. 1971. The genus Agrostis L. in Eastern Fennoscandia. Taxonomy and distribution. Fl. Fennica 5: 1-209.

\section{Appendix 1. Selected material examined.}

Agrostis boyacensis Swallen \& García-Barr. COLOMBIA. Boyacá: Nevado del Cocuy, Alto Valle de Las Lagunillas, 4000-4300 m, 12 Sep. 1938, Cuatrecasas \& García Barriga 1459 (US).

Agrostis breviculmis Hitchc. COLOMBIA. Amazonas: Nueva Granada, 1783-1808, Mutis 6079 (MA). Cundinamarca: ChisacáSumapaz, Reserva de Bosque Andino, subida de Chisacá, 3200 m, 13 Sep. 1994, Fernández Alonso et al. 11628 (MA). Santander: E de Bucaramanga, 2700 m, 18 Dec. 1948, Araque Molina \& Barkley 18 S389 (LIL); Páramo de Santurbán, near Vetas, 3950-4160 m, 17 Jan. 1927, Killip \& Smith 17573 (P). ECUADOR. Azuay: Parque Nacional Cajas, NW of Cuenca, 3700 m, 21 Apr. 1990, Peterson et al. 8855 (QCNE); CumbeOna, Páramo grassland, 21 Sep. 1987, Ramsay \& Merrow-Smith 651 (QCNE). Bolivar: Rd. Ambato-Guaranda, $12 \mathrm{~km} \mathrm{~W}$ of intersection betw. old \& new rd., 4150 m, 1 Aug. 1985, Laegaard 54815 (QCNE). Carchi: Volcán Chiles, 9 km of Tufiño, páramo espeletias, 10 Mar. 1992, Laegaard 101676 (QCNE). Chimborazo: Collanes Valley, Páramo de Los Altares, 3 Sep. 1987, Ramsay et al. 356 (QCNE); $7 \mathrm{~km}$ along páramo rd. from new rd. Ambato-
Guaranda towards Carihuairazo, 15 Feb. 1999, Laegaard 19595 (QCNE); Urbina, toward to Monte Chimborazo, páramo, $4250 \mathrm{~m}, 24$ July 1939, Asplund 7797 (B, LIL, P). Cotopaxi: Páramo de Laguna Salayampe, E of Latacunga, 14-15 May 1985, Laegaard 54141 (QCNE); Filo N NE del Volcán Cotopaxi, 4000 m, 19 Dec. 1979, Halloy A-835, A-822 (LIL); SW slope of the volcano, $4000 \mathrm{~m}, 3$ July 1939, Asplund 7492 (LIL, P); Oct. 1856, Remy s.n. (P). Imbabura: NE side of Cayambe Mtn., 12 Dec. 1961, Cazalet \& Pennington 5753 (B). Napo: Laguna San Marcos, NE of Volcán Cayambe, extensive flat plain $\mathrm{S}$ of the lake, predominantly marshy, $77^{\circ} 58^{\prime} \mathrm{W}$, $00^{\circ} 07^{\prime} \mathrm{N}, 3370 \mathrm{~m}, 8$ July 1980, Ollgaard et al. 34011 (SI), Ollgaard et al. 34061 (SI); NW slope of Antisana, Lago MaucaMachay, windswept high plain with extended swampy areas, $78^{\circ} 10^{\prime} \mathrm{W}, 00^{\circ} 27^{\prime} \mathrm{S}, 4350 \mathrm{~m}, 2$ Nov. 1979, Holm-Nielsen 20730 (SI). Pichincha: Páramo de Mojanda, 24-27 June 1984, Laegaard 52321 (QCNE); Laguna Mauca-Machay, lado WNW del Antisana, 4330 m, 28 Jan. 1980, Halloy B-40 (LIL); vic. of Quito, gravelly páramo, 3800 m, 30 May 1939, Asplund 6605 (LIL); Pichincha, 5 June 1931, Benoist 4410 (P); Eablahuasi sur les pentes NW du Pichincha, 21 May 1931, Benoist 4347 (P). Tungurahua: along trail Mesa Tablon to Limpiopungo of Laguna Pisayambo, 14 Jan. 1999, Laegaard 19454 (QCNE).

Agrostis foliata Hook. f. COLOMBIA. Caldas: Cordillera Central, Páramo del Quindío, 4100-4300 m, 15-20 Aug. 1922, Pennel \& Hazen 9855 (WU), 9956 (BAA, WU); vertiente occidental, Nevado del Ruiz, 4300-4500 m, 5 May 1940, Cuatrecasas 9262 (LIL); 31 Oct. 1952, Humbert et al. 27064 (P). Cauca: Cordillera central, vertiente occidental, abajo del Puracé en la Quebrada del Arroyo San Juan, 3900-3650 m, 24 July 1943 , Cuatrecasas 14731 (P); 3700-3900 m, 12 June 1922, Pennell \& Killip 6568 (WU); faldas del Volcán del Puracé, 3650-3850 m, Cleef 618 (P). Tolima: Cordillera Central, Nevado del Tolima, 4400 m, 15 May 1932, Cuatrecasas 2513 (MA); Cuatrecasas 2984 (BAA, MA); Lomas du Pie du pico Tolima, Goudot s.n. (P). ECUADOR. Carchi: Páramo del Ángel, Oct. 1978, Roig s.n. (MERL); Volcán Chiles along rd. $9 \mathrm{~km} \mathrm{~W}$ of Tufiño, 10 Mar. 1992, Laegaard 101677 (QCNE); Tulcán, frontera con Colombia, faldas del Volcán Chiles, Nov. 1993, Palacios 11859 (QCNE); Cantón Tulcán, Páramo, Rancho Morán, 3200 m, 13 July 1935, Mexia 7498 (BAA); Tulcán-Maldonado rd., $4 \mathrm{~km} \mathrm{~W}$ of Tufiño, Monte Redondo área, 3475 m, 12 Apr. 1978, Luteyn 5710 (P). Chimborazo: El Altar, N side of the volcano, Canoningo peak, Sklenar 88-3 (NY). Cotopaxi: Parque Nacional Cotopaxi, Rio Pita, bosque pluvial sub-alpino, 4000 m, 14 Dec. 1990, Ceron 12595 (QCNE). Napo: Rd. Pifo-Papallacta, $\mathrm{N}$ of antennas at Paso de la Virgen, superpáramo, 4250-4400 m, 13 Mar. 1985, Laegaard 53860 (QCNE). Pichincha: Dec. 1864, Isern 132 b (MA); Laguna de Hoyas, Páramo de Guamaní, 9 Mar. 1987, Ramsay 226 (QCNE); along rd. to Refugio, Cayambe volcano, 4400-4500 m, 1 Mar. 1988, Laegaard 70495 (QCNE); Km. 48 rte. Quito-Papallacta, cordillera oriental, 4000 m, 1 May 1947, Aubert de la Rue s.n. (P); Páramos de Pichincha, Oct. 1856, Remy s.n. (P); Pichincha, 4500 m, 9 Nov. 1946, Aubert de la Rue s.n. (P); Monte Pichincha, Sep. 1887, Sodiro s.n. (W); Monte Pichincha near Quito, 4100-4500 m, 17 Aug. 1923, Hitchcock 21053 (BAA); Crescit in arenis vulc. Intis Pichincha, $4500 \mathrm{~m}$, July 1918, Mille s.n. (BAB, Q). Pichincha-Napo: Volcán Antisana, betw. Campamento IMAP \& Laguna Micacocha, moist \& dry grass-páramo, swamps around the lake, 7 Mar. 1992, Laegaard 101598 (QCNE); Jan. 1865, Isern 145 (MA). Tungurahua: N slopes of Volcán Tungurahua, Ramsay et al. 254 (QCNE); along trail Mesa Tablon to Limpiopungu $\mathrm{S}$ of Laguna Pisayambo, superpáramo without traces of fires, 14 Jan. 1999, Laegaard 19457, 19480 (QCNE); Cordillera de Llanganates, páramo de Jaramillo, 2-4 Nov. 1984, Laegaard 53292 (QCNE); ca. $5 \mathrm{~km}$ SE of Laguna Pisayambo, Las Tolas, 3900-4000 m, 13 June 1999, Laegaard 19428 (QCNE); Cantón Patate, Parque Nacional Llanganates, faldas del cerro Pan de Azúcar, Páramo 
de Soguillas-Cerro Pan de Azúcar, 13 Oct. 1998, Vargas et al. 2817 (QCNE); volcano, humid area above tree limit, 18-19 Nov. 1983, Korning \& Thomsen 47336 (QCNE).

Agrostis tolucensis Kunth var. tolucensis. ECUADOR. Azuay: Mt. Azuay, Spruce 6097 (BAA, K, US). Bolivar: ca. Km. 20 Guaranda-Riobamba, 3300-3400 m, 10 July 1990, Laegaard 71726 (QCNE). Loja: Old Campamento y Fierro Urco, 8 Sep. 1998, Laegaard 19112 (QCNE). Pichincha: 5 June 1931, Benoist 4401, $4402(\mathrm{P})$.

Agrostis tolucensis Kunth var. andicola (Pilg.) Rúgolo \& A. M. Molina. ECUADOR. Azuay: Páramos de Soldadas-Angas, 14 Feb. 1988, Laegaard 70114 (QCNE). Bolivar: $45.7 \mathrm{~km} \mathrm{SW}$ of Ambato on Hwy. to Guarando, 3 May 1990, Peterson 8977 (QCNE); Cruces de Los Arenales, $78^{\circ} 54^{\prime} \mathrm{W}, 01^{\circ} 25^{\prime} \mathrm{S}, 4160-4200 \mathrm{~m}, 1$ Mar. 1992, Laegaard 101494 (BAB, QCNE). Cañar: Panamerican Hwy., entre Cañar y Biblian, 29 Aug. 1984, Laegaard 52758 (QCNE). Chimborazo: In pascuis Monte Chimborazo, Sodiro s.n. (P); betw. Urbina \& Mt. Chimborazo, 3600-4500 m, 4 Oct. 1923, Hitchcock 21999 (F, US); crescit in páramos Chimborazo, 1890, Sodiro 11/6 (Q); Cruce de Los Arenales-Chimborazo Km 5. dune-sand, 11 May 1992, Laegaard 102782 (QCNE); Collanes Valley, Páramo de los
Altares, 3 Sep. 1987, Ramsay \& Merrow-Smith 384 (QCNE); camino de Riobamba a Pallatanga, Oct. 1978, Roig s.n. (MERL); Parque Nacional Sangay, near Campanilla, $78^{\circ} 29^{\prime} \mathrm{W}, 1^{\circ} 38^{\prime} \mathrm{S}, 3300-3500 \mathrm{~m}$, 24 Mar. 1984, Laegaard 51876 A (QCNE). Cotopaxi: Illiniza N \& Illiniza S, 4750 m, 2 May 1990, Peterson 8968 (QCNE); Parque Nacional Cotopaxi, 25 Feb. 1992, Laegaard 101445 (QCNE). Imbabura: Lago San Marcos, Cayambe, 25 Nov. 1961, Cazalet \& Pennington 5328 (B); SW slopes of the Volcano Cotacachi, 9 Nov. 1983, Boysen et al. 45647 (QCNE). Loja: along rd. to Fierro Urcu, ca. $10 \mathrm{~km}$ from main rd. Loja-Saraguro, 8 June 1998, Laegaard 18860 (QCNE). Napo: Cordillera de los Llanganates, Laguna Encantada, Lakeshore, $78^{\circ} 12^{\prime} \mathrm{W}, 01^{\circ} 11^{\prime} \mathrm{S}, 3400 \mathrm{~m}, 17$ Mar. 1983, Holm-Nielsen 41977, 41991 (SI). Napo-Pastaza: NE of Cayambe Mtn., 12 Dec. 1961, Cazalet \& Pennington 5579 (B). Pichincha: crescit in silv. occidental prope Pichincha, Aug. 1889, Sodiro s.n.(Q); Laguna Negra de Mojanda, 29 Feb. 1997, Laegaard 101485 (QCNE); ca. Cotocollao, Aug. 1886, Sodiro s.n. (BAB, Q); ca. de Quito, Mar. 1886, Sodiro 23/2 (Q, W). Tungurahua: Cantón Patate, Parque Nacional Llanganates, 14 Oct. 1998, Vargas et al. 2881 (QCNE); Km. 33.4, Zumbagua-Latacunga, $78^{\circ} 45^{\prime} \mathrm{W}, 00^{\circ} 55^{\prime} \mathrm{S}$, 3885 m, 26 July 2001, Laegaard et al. 21468 (SI). 